\title{
The End of the Cold War: Its Dynamics and Critical Factors
}

\author{
Ahmad Fuad Fanani \\ Lecturer at the Department of International Relations, Faculty of Social and Political Sciences State \\ Islamic University (UIN) Syarif Hidayatullah, Jakarta; Research Director at MAARIF Institute for \\ Culture and Humanity, Jakarta \\ Email: fuadfanani27@gmail.com
}

\begin{abstract}
Abstrak
Tulisan ini akan membahas berakhirnya Perang Dingin dan factor kritis yang mempengaruhi keberakhiran tersebut. Telah dikemukakan bahwa Perang Dingain merupakan konflik ideologi antara Uni Soviet dan Amerika Serikat. Namun, konflik antara negara adi kuasa telah memicu konfrontasi militer dan pendekatan keamanan di dunia setelah berakirnya Perang Dunia Kedua. Akibatnya, banyak Negara, terutama negara dunia ketiga menjadi korban persaingan ideologi antara Amerika Serikat dan Uni Soviet.

Kata kunci: pendekatan antar - sistemik, konflik ideologi, runtuhnya komunisme, kebijakan luar negeri
\end{abstract}

\begin{abstract}
This essay will discuss the end of the Cold War and the critical factors which influenced its ending. It has been suggested that the Cold War actually was the ideological conflict between the Soviet Union and the United States. However, the conflict between the superpowers has triggered the military confrontation and security approach in the world after the end of the Second World War. As a result, many countries, especially the Third World countries became victims of the ideological rivalry between the United States and the Soviet Union.

Keywords: inter-systemic approach, ideological conflict, collapse of communism, foreign policy
\end{abstract}

\section{INTRODUCTION}

The end of the Cold War is widely recognized as the new era of international relations until today. This event is arguably as the most momentous event in international politics since the end of the World War II. This event, for some scholars, was also assumed as the fundamental changes in the dynamic of international politics. ${ }^{1}$ This is because there was a shift in the international system from bipolarity (the United States and the Soviet Union) to multi polarity. Besides that, the end of the Cold War also gave many lessons. One of the lessons was providing the type of historically relevant event. This event suggested the revolutionary change in the status of state, the inde- pendence of nations, the policy of agendas and priorities among many countries in the world. ${ }^{2}$ Indeed, many countries hoped that this new era would distance them from military security paradigm and could encourage them to build a peaceful world.

Regarding the above issue, this essay will assess the end of Cold War as well as its dynamics and factors which stimulated its ending. Specifically, the following questions will guide trajectory of this essay: What was the Cold War? When and how did it end? In attempt to answer these questions, this essay will be divided into three sections. The first section examines the debate about the Cold War. The second section 
assesses the transformation of the Cold War in 1970s and 1980s which contributed to the ending of the Cold War. The third section analyses the collapse of Soviet Union and other factors which resulted in the end of the Cold War.

\section{ANALYSIS}

\section{WHAT WAS THE COLD WAR?}

The debate whether the Cold War was a contest of two ideologies -liberal democracy and MarxismLeninism-or was the contestation of power and material drew interests of many countries still occur until today. The proponents of realism theory assert that the conflicting ideologies were irrelevant to the cause of the Cold War. For them, the Cold War was about two 'structural' features of international politics which arranged the interactions between states in general and the superpowers in particular. As a result, many events during the Cold War were constrained and determined by US and Soviet foreign policy decisions. ${ }^{3}$ Thus, this group believes that the Cold War happened as the need to create the balance of power in the world and as the strategy of the superpowers to widen their real interests.

However, many scholars such as John Gaddis, Richard Rosecrance, Arthur Sein, and John Mueller argue that the Cold War was the conflict that arose because of incompatible ideologies and it ended only when Soviet ideology lost. The assessments of the Cold War that was focusing only in material power, changes of its distributions, and external threats would not be enough and did not account for many events after 1947. Besides that, it is also clear that Marxist-Leninist ideology that shaped Soviet foreign policy and the liberal democratic values were inherent in US goals. In fact, the Cold War and the bipolar structure of the postwar international politics sprang from a contest of ideas and an ideological conflict which employed many strategies. ${ }^{4}$ Thus, they believed that the conflict of ideology was the main factor that caused the Cold War.

Similarly, an 'inter-systemic approach' also considers the Cold War as the conflict between two rival social systems which caused many things such as nuclear weapons and wars in the Third World countries. This group argues that the Cold War was more than great power conflict. This is because it recognized the external factor which had supported the winning of one social system over another. ${ }^{5}$ The incompatible social systems between the United States and the Soviet Union and the clash between them actually had long historical root since the Bolshevik revolution in 1918. The ideology of both superpowers evolved over time and made efforts to persuade other countries to follow them. ${ }^{6}$

Meanwhile, the superpowers often used the military power and intervention toward other countries to spread their ideologies. In addition, they made many strategies to strengthen their involvement in Europe, the Middle East, and East Asia. During the Cold War era, Truman and Eisenhower doctrines were widely known. The doctrines had a goal to avoid the spread of communism in many countries. Then, several countries such as in Western Europe and Japan joined the United States in waging the Cold War against communism. ${ }^{7}$ On the contrary, some states also joined the Soviet Union and adopted the communism ideology.

It was not surprising because after the power vacuum in Europe post World War II, both the superpowers seeked for European allies against one another. The United States planned to help the West European states to find the important strategy to sustain viable balance against the Soviet Union. The United States and West European countries established the North Atlantic Treaty Organization (NATO) in April 1949. In contrast, the Soviet Union led alliance in Eastern Europe which was formally constituted in May 1955. The alliance which initially based on bilateral defense agreements was recognized as the Warsaw Treaty Organization (Warsaw Pact). ${ }^{8}$

It is important to note that many Third World countries became main victims of the Cold War from the mid-1970s through the extension of the superpowers tensions to their territories. Central America, Angola, Afghanistan, Indonesia, Indochina, and Korea 
were examples of countries which future was wrecked by the superpowers' involvement. In fact, the October war in the Middle East in 1973, the civil war in Angola in 1975, the coup in South Yemen in 1976, the war in the Horn of Africa in 1977-78, and the war in Afghanistan in 1979 could be identified as the invasion of the superpowers to the Third World countries. ${ }^{9}$ Unfortunately, the involvement of the superpowers was very long indeed and several Third World countries felt difficult to determine their nationality and freedom. In this respect, many of the elites in the Third World countries showed their willingness to adopt Cold War ideologies for the purposes of domestic politics, development and mobilization. ${ }^{10}$

\section{THE TRANSFORMATION OF THE COLD WAR}

It has been argued that since the late 1970s the international world had witnessed two quiet shifts in the relationships between the United States and the Soviet Union. Firstly, in the last years of the Carter presidency and after the election of President Reagan in 1980, the superpowers reevaluated their policies and rhetoric reminiscent of the Cold War. Secondly, this new period was followed by gradual complete breakdown in 'normal' relations between Washington and Moscow. ${ }^{11}$ Unfortunately, this new paradigm did not receive enough support from policy makers both in the United States and the Soviet Union. Inevitably, this ideas triggered debates among elites and pundits from both countries. As a result, Moscow then saw no possibility to engage in serious negotiation with Washington. ${ }^{12}$

However, the duration of serious conflict between the United States and the Soviet Union during 1980s was short. After President Reagan's second election triumphed in 1984, the broken dialogue between the superpowers was re-evaluated. At the same time, the emergence of Mikhail Gorbachev as the leader of the CPSU (Communist Party of Soviet Union) in March 1985 gave significant factor to build the new relationship between them. ${ }^{13}$ Indeed, after 1985 the Soviet Union made a clear decision and policy to establish a fundamentally new type of relationship with the West. The transformation in U.S-Soviet relations after 1984 was only possible to occur because of the serious engagement of both Reagan and Gorbachev. ${ }^{14}$ Hence, the relation between two states in this era was probably better than any periods since the Cold War.

It is interesting to note that the new relationship between the superpowers gave many implications for their policies toward the Cold War. Indeed, this affected their decision toward military strength and armed power, nuclear weapons, and also their defense from enemies. In the 1980s, the Soviet Union gradually withdrew its troops from its Western front areas. Soviet also followed its decision by marking a lower profile in regional conflicts such as in Afghanistan, Africa, and Middle East. Later, Soviet also terminated its occupation in Afghanistan. Both superpowers then signed Security Council resolution 678 in November 1990 which contained use of force to expel Iraq from Kuwait. ${ }^{15}$ In addition, Gorbachev regime also approved the 1987 treaty on intermediate nuclear forces. Then, the Soviet Union agreed to remove many more missiles from the European areas than did the United States. ${ }^{16}$ The above changes implied that both superpowers realized that the Cold War no longer existed and the international world had to transform.

\section{THE END OF THE COLD WAR AND ITS CRITICAL FACTORS}

It should be noted that the final stage of the Cold War (1985-1991) marked a radical departure in EastWest relation. Some experts also called the years 1985 1991 as the endgame of the Cold War. ${ }^{17}$ By considering this stage, there was no single cause that made the end of the Cold War. According to Richard K. Herrmann and Richard Ned Lebow, ${ }^{18}$ there are five critical turning points to the end of the Cold War. Firstly, the rise of Gorbachev that brought a reform nature in the Soviet political system. Secondly, Soviet's withdrawal from regional conflict that signed a new commitment of the superpowers to avoid use of military force. Thirdly, arms control which marked by evaluating of nuclear weapons. Fourthly, the emancipation of Eastern Europe in 1989. Fifthly, the reunifi- 
cation of Germany which was recognized by international world as the end of the Cold War.

In this context, the role of Gorbachev and his policy to set up new arms control agreements was very important factor to end the Cold War. Regarding his policy, the Soviet Union agreed to remove their theater weapons system and reduce their strategic arsenals. Indeed, the Soviet Union also decided to withdraw its troops from Afghanistan, Angola, and Nicaragua which became a necessary step for ending the Cold War. In the Soviet Union intern, Gorbachev also introduced domestic political reforms which were more representative and transparent. ${ }^{19}$ When Gorbachev created more democratic institutions, he was able to make more credible commitments about the peacefulness of Soviet international intentions. ${ }^{20}$ From the above explanations, the Soviet reform certainly gave great contribution to the end of the Cold War.

In this respect, we should consider the Reagan's factor which also contributed to the end of the Cold War. Reagan's commitment to anti-nuclearism and its potential for transforming the U.S-Soviet Union confrontation had encouraged the creation of the peaceful world. It was difficult to imagine what would happen if Gorbachev's ideas did not meet with Reagen's commitment. As a result, some experts argued that Reagan's anti-nuclearism was more important than his administration's military buildup in catalyzing the end of the Cold War. ${ }^{21}$

Therefore, the Cold War ended when the structure of the international system and the dynamics of the world political economy no longer supported it. In fact, although the Cold War was not more than the Soviet Union-the United Stated relation, their competition in terms of strategic, political, ideological, and economy, had influenced significantly on its development. And the rivalry finally ended because the Soviet Union strength eroded and the Soviet empire collapsed. Probably, the Soviet Union's incapability to compete economically with the United States was the decisive factor in its collapse. ${ }^{22}$ In this respect, the collapse of Soviet superpower gave direct effect to the end of the Cold War. It then signed the end of bipolar era and ushered a period of geopolitical transition. ${ }^{23}$

Furthermore, the collapse of Communism as an ideology also preceded the collapse of Soviet military. Even though the ideological model of the Soviet Union (communism) had been adopted by some Third World countries, its continued repression at home and oppression abroad such as in Hungary in 1956, Czechoslovakia in 1968, and Afghanistan in 1979, stained Communism's image. ${ }^{24}$ In contrast, the United States and its allies continued to campaign for human rights and prosperity issues which were close to liberal-capitalist ideology. The United States successfully gained many supports from the West and also achieved economic booming which was very beneficial for its position in the world. The success of the world capitalist system to avoid the great depression and the failure of the world communist system were the key factors to end the Cold War. ${ }^{25}$ As a result, it can be said that the end of the Cold War was possible to happen because one of the ideologies had won the completion over another ideologies.

It has been asserted that the Cold War began as a struggle for influence in central Europe that quickly led to the division of Germany and the imposition of Soviet-style governments throughout most regions in Eastern Europe. The conflict became less severe after the United States and its allies in the late 1960s and 1970s accepted the division of Germany and the territorial arrangements that the Soviet Union had imposed after 1945. Hence, the Cold War ended when Eastern European states became free to choose their governments without Soviet interference. In addition, the Cold War ended because Germany was reunified. ${ }^{26}$ The condition implied that the influence of the Soviet Union in Eastern Europe was disappeared. Also, the Soviet Union could not expand its influence and power to other countries.

The above condition also corresponded with the new paradigm which was adopted by many states in the late of the twentieth century. Many countries preferred to avoid the ideology that did not give benefits for their countries. The end of the Cold War 
means that the evaporation of the major challenge (the Soviet Union) to the current initial status quo (the United States) had appeared. Indeed, the Soviet Union efforts after its collapse at liberalization, democratization and privatization suggested that the Soviet Union had become a member of the liberal states. ${ }^{27}$ Consequently, it is commonly argued that the collapse of the Soviet Empire in Eastern Europe in the late 1989 and the disintegration of the Soviet Union and Communism in 1991 had been marked as the end of the Cold War. It had also been suggested that the Cold War was principally about the ideological conflict between the Soviet Union and the United States and its Western allies. ${ }^{28}$ As a result, when the Soviet Union changed its attraction to and support of an ideology that threatened the West, the Cold War came to an end. Also, by the spring of 1989, actually the necessary and sufficient condition for ending the Cold War was in place. ${ }^{29}$

\section{CONCLUSION}

The transformation of the Cold War in 1970s and 1980s had been made after both of the superpowers took initiatives to re-evaluate their relationship. Thus, the new relationship resulted in many impacts on the process for ending the game in the Cold War. Finally, the Cold War then ended when the structure of international system and the dynamics of the world political economy did not support it. Although there are many opinions about the date to end the Cold War, some experts argued that this ending had been signed by the collapse of the Soviet Union in Eastern Europe in 1989, the end of communism, and the reunited of Germany in 1991.

\section{ENDNOTES}

1 D.A. Baldwin, 'Security Studies and the End of the Cold War', World Politics, Vol. 48, No. 1 (Oct. 1995), p. 117.

2 R.K. Herrmann, 'Learning from the End of the Cold War', in R.K. Herrmann and R.N. Lebow (eds.), Ending the Cold War: Interpretations, Causation, and the Study of International Relations, Palgrave Macmillan, Houndmills, 2004, p. 219.

3 M. Kramer, 'Ideology and the Cold War', Review of International Studies (1999), 25, p. 539

4 M. Kramer, p. 540.
5 F. Halliday, 'The Cold War and Its Conclusion: Consequences for International Relations Theory', in R. Leaver \& J.L. Richardson (eds.), The Post Cold War Order: Diagnoses and Prognoses, Allen \& Unwin, Sydney, 1993, p. 20.

6 R.K. Herrmann and R.N. Lebow, 'What Was the Cold War? When and Why Did it End?', in R.K. Herrmann and R.N. Lebow (eds.), Ending the Cold War: Interpretations, Causation, and the Study of International Relations, Palgrave Macmillan, Houndmills, 2004,p. 7.

O.A. Westad, 'The New International History of the Cold War: Three (Possible) Paradigms', Diplomatic History, Vol. 24, No. 4 (Fall 2000), p. 555.

8 M. Kramer, p. 547.

9 O. Osterud, 'Intersystemic Rivalry and International Order: Understanding the End of the Cold War', in P. Allan \& K. Goldmann (eds.), The End of the Cold War: Evaluating Theories of International Relations, Martinus Nijhoff Publishers, London, 1992, pp. $19-20$

10 O.D Westad, p. 561

11 M. Cox, 'Introduction: Beyond the Cold War: Superpowers at the Crossroads?', in M. Cox (ed.), Beyond the Cold War: Superpowers at the Crossroads?, University Press of America \& The Miller Center University of Virginia, New York, 1990, p. xvii

12 M. Cox, p. xvii-xviii.

13 M. Cox, p. xviii.

14 M. Cox, p. 44.

15 O. Osterud, pp. 20

16 R.N. Lebow, 'The Long Peace, The End of the Cold War, and the Failure of Realism', International Organizations, Vol. 48, No. 2 (Spring, 1994), p. 261

17 R.K. Herrmann and R.D. Lebow, pp. 17

18 R.K. Herrmann and R.D. Lebow, pp. 8-11.

19 R.K. Herrmann and R.D. Lebow, pp. 12

20 M.L. Hass, 'The United States and the End of the Cold War: Reactions to Shifts in Soviet Power, Policies, or Domestics Politics?', International Organization, Vol. 61, No. 1 (Winter, 2007), pp. 153154

21 D. Deudney \& G.J. Ikenberry, 'Who Won the Cold War', Foreign Policy, No. 87 (Summer, 1992), pp. 127-128.

22 D.S. Painter and Melvyn P. Leffer, 'Epilogue: The End of the Cold War', in M.P. Leffer \& D.S. Painter (eds.), Origins of the Cold War: an International History, Routledge, New York, 1994, p. 317.

23 J. Nijman, 'The Limits of Superpower: The United States and the Soviet Union since World War II', Annals of the Association of American Geographers, Vol. 82, No. 4 (Dec. 1992), p. 692.

24 D.S. Painter and Melvyn P. Leffer, p. pp. 319-320

25 D.S. Painter and Melvyn P. Leffer, pp. 320-321.

26 R.K. Herrmann and R.D. Lebow, pp. 13

27 D. Lemke, 'The Continuation of History: Power Transition Theory and the End of the Cold War', Journal of Peace Research, Vol. 34, No. 1 (Feb. 1997), p. 32.

28 J. Mueller, 'What Was the Cold War About? Evidence from Its Ending', Political Science Quarterly, Volume 119, Number 4, 200405, p. 609.

29 J. Mueller, p. 631. 


\section{BIBLIOGRAPHY}

Baldwin, D.A., 'Security Studies and the End of the Cold War', World Politics, Vol. 48, No. 1 (Oct. 1995), pp. 117-141.

Cox, M., 'Introduction: Beyond the Cold War: Superpowers at the Crossroads?', in M. Cox (ed.), Beyond the Cold War: Superpowers at the Crossroads?, University Press of America \& The Miller Center University of Virginia, New York, 1990.

Deudney, D. \& Ikenberry, G.J., 'Who Won the Cold War', Foreign Policy, No. 87 (Summer, 1992), pp. 123-128 \& 130-138.

Halliday, F., 'The Cold War and Its Conclusion: Consequences for International Relations Theory', in R. Leaver \& J.L. Richardson (eds.), The Post Cold War Order: Diagnoses and Prognoses, Allen \& Unwin, Sydney, 1993.

Hass, M.L., 'The United States and the End of the Cold War: Reactions to Shifts in Soviet Power, Policies, or Domestics Politics?', International Organization, Vol. 61, No. 1 (Winter, 2007), pp. 145-179

Herrmann, R. K., 'Learning from the End of the Cold War', in R. K. Herrmann and R.N. Lebow (eds.), Ending the Cold War: Interpretations, Causation, and the Study of International Relations, Palgrave Macmillan, Houndmills, 2004.

Herrmann, R. K. and Lebow, R.N., 'What Was the Cold War? When and Why Did it End?', in R. K. Herrmann and R.N. Lebow (eds.), Ending the Cold War: Interpretations, Causation, and the Study of International Relations, Palgrave Macmillan, Houndmills, 2004.

Kramer, M., 'Ideology and the Cold War', Review of International Studies (1999), 25, pp. 539-576.

Lebow, R.N., 'The Long Peace, The End of the Cold War, and the Failure of Realism', International Organizations, Vol. 48, No. 2 (Spring, 1994), pp. 249-277.

Lemke, D., 'The Continuation of History: Power Transition Theory and the End of the Cold War', Journal of Peace Research, Vol. 34, No. 1 (Feb. 1997), pp. 23-36.

Mueller, J., 'What Was the Cold War About? Evidence from Its Ending', Political Science Quarterly, Volume 119, Number 4, 2004-05, pp. 609-631.

Nijman, J., 'The Limits of Superpower: The United States and the Soviet Union since World War II', Annals of the Association of American Geographers, Vol. 82, No. 4 (Dec. 1992), pp. 681-695.

Osterud, O., 'Intersystemic Rivalry and International Order: Understanding the End of the Cold War', in P. Allan \& K. Goldmann (eds.), The End of the Cold War: Evaluating Theories of International Relations, Martinus Nijhoff Publishers, London, 1992.

Painter, D.S. and Leffer, M.P., 'Epilogue: The End of the Cold War', in M.P. Leffer \& D.S. Painter (eds.), Origins of the Cold War: an International History, Routledge, New York, 1994.

Westad, O.A., 'The New International History of the Cold War: Three (Possible) Paradigms', Diplomatic History, Vol. 24, No. 4 (Fall 2000), pp. 551-565. 